\title{
Effects of Dietary Inclusion Level of Microwave-Dried and Press-Defatted Black Soldier Fly (Hermetia illucens) Larvae Meal on Carcass Traits and Meat Quality in Broilers
}

\author{
Byeonghyeon Kim (D), Hye Ran Kim, Seul Lee (D), Youl-Chang Baek, Jin Young Jeong (D, Han Tae Bang, \\ Sang Yun Ji * and Seol Hwa Park*
}

check for

updates

Citation: Kim, B.; Kim, H.R.; Lee, S.; Baek, Y.-C.; Jeong, J.Y.; Bang, H.T.; Ji, S.Y.; Park, S.H. Effects of Dietary Inclusion Level of Microwave-Dried and Press-Defatted Black Soldier Fly (Hermetia illucens) Larvae Meal on Carcass Traits and Meat Quality in Broilers. Animals 2021, 11, 665. https://doi.org/10.3390/ani11030665

Academic Editor: Grazia Pastorelli

Received: 25 January 2021

Accepted: 24 February 2021

Published: 2 March 2021

Publisher's Note: MDPI stays neutral with regard to jurisdictional claims in published maps and institutional affiliations.

Copyright: (c) 2021 by the authors. Licensee MDPI, Basel, Switzerland. This article is an open access article distributed under the terms and conditions of the Creative Commons Attribution (CC BY) license (https:/ / creativecommons.org/licenses/by/ $4.0 /)$.
Animal Nutrition \& Physiology Team, Rural Development Administration, National Institute of Animal Science, Wanju 55365, Korea; osorikim619@gmail.com (B.K.); ococ1004@korea.kr (H.R.K.); tabababy@korea.kr (S.L.); chang4747@korea.kr (Y.-C.B.); jeong73@korea.kr (J.Y.J.); banght80@korea.kr (H.T.B.)

* Correspondence: syjee@korea.kr (S.Y.J.); shwa6560@korea.kr (S.H.P.)

Simple Summary: Insects are a potential source of protein for broiler diets because of the high price and limited supply of soybean. Black soldier fly (Hermetia illucens; HI) larvae are promising candidates as an alternative protein source to soybean meal; a microwave drying method is a convenient approach for producing HI larvae meal (HILM), as it is time- and energy-efficient. However, whether microwave-dried HILM is an appropriate protein source for producing healthy chickens for consumers has not been evaluated. Therefore, we examined the effect of 0,25 , and $50 \%$ dietary replacement of soybean meal with HILM on carcass traits, meat quality, and safety. We observed satisfactory results for the meat quality and fatty acid composition without detrimental effects on undesirable heavy metal residues in the meat. However, the carcass weight was reduced in 50\% HILM-substituted diets, suggesting that a low level of HILM is beneficial. Microwavedried HILM is a promising ingredient for broiler diets. However, further research is needed to overcome the lowering of the carcass weight in terms of utilization efficiency by improving the manufacturing process.

Abstract: Limited information is available regarding the use of microwave-dried Hermetia illucens larvae meal (HILM) as a dietary protein source for broiler diets. Therefore, we investigated the effects of microwave-dried HILM on carcass traits, meat quality, fatty acid (FA) profiles of abdominal fat and meat, and heavy metal residues of the meat in broilers. A total of 126 male broilers were randomly assigned to three dietary treatment groups ( 6 replicates and 7 birds/pen): a control diet and two experimental diets in which soybean meal was replaced with 25 or 50\% HILM. The broilers were slaughtered at 35 days; the carcasses were weighed, and breast and leg meats were excised from 12 birds per treatment ( 2 birds/pen) for meat analysis. The breast meat quality and proximate composition showed satisfactory results. For the higher HILM diet, the content of saturated FA in the abdominal fat was increased and that of polyunsaturated FA was decreased $(p<0.001)$; the FA profile of leg meat did not significantly differ between groups. The concentrations of undesirable heavy metals in the HILM and leg meat were below permissible levels. However, the carcass weight was decreased $(p<0.001)$ in the 50\% HILM group. Microwave-dried HILM is a potential ingredient for broiler diets, with up to $25 \%$ substitution showing no detrimental effects on carcass traits, meat quality, FA profiles, and heavy metal residues in the meat.

Keywords: broiler chicken; fatty acid profile; heavy metal; Hermetia illucens larvae meal; meat quality

\section{Introduction}

Black soldier fly (Hermetia illucens) larvae have been considered as a dietary source for animals because of their ability to convert organic waste to edible biomass [1,2]. Furthermore, developing black soldier fly larvae as an animal feed is a potential solution 
for concomitant problems related to limited food and feed given the increasing world population [3].

Hermetia illucens larvae meal (HILM) has been evaluated as a valuable protein source for fish and birds [4-6]. HILM also contains high protein and amino acid contents, which are comparable to those in soybean meal (SBM) [1]. The nutrient composition of HILM can be affected by the feeding media and rearing method of the larvae [2,7]. The fatty acid (FA) profiles of HILM can be altered by the food sources; however, saturated fatty acid (SFA) levels are typically higher than unsaturated fatty acid (UFA) levels [1]. Despite its potential advantages, toxicity can be caused by the accumulation of heavy metals in the HI larvae body via feeding of contaminated media $[8,9]$.

HILM showed satisfactory effects on carcass traits and meat quality except for negative modulation of the FA profile in the meat of broiler quails and chickens because of the different FA composition compared with that of SBM [9-11]. Because the SFA content is higher than the UFA content in the HILM, the FA profile in meat was altered [5,9]. Moreover, the high content of SFA in the diet may affect the FA profile of abdominal fat because of higher fat deposition compared to polyunsaturated fatty acid (PUFA) [12]. Schiavone et al. [9] also reported that heavy metals and the arsenic level in chicken breast meat of broilers fed the HILM did not exceed the maximum allowable limits by the European Union. Moreover, HILM contains high levels of chitin, which is indigestible and can decrease protein digestibility [13]. Overall, a low inclusion level (up to 10\%) of HILM appears to be suitable for broiler diets in terms of the growth performance, intestinal morphology, and FA profile of chicken meat $[9,14]$.

Although HI larvae are a good protein source for animals in terms of their nutrient composition, appropriate processing is required to ensure nutrient availability. The nutritional quality of HILM is not only altered by substrates but also affected by the drying process, and its digestibility varies depending on the drying method used [15]. The microwave drying method has many advantages compared to conventional drying $\left(60^{\circ} \mathrm{C}\right.$ in a drying oven) in terms of efficiency and energy use. Microwave drying transfers thermal energy from the center to the surface of products, whereas the conventional drying method involves the opposite process and is slow [16]. Microwave drying requires less space, is simpler to operate, and has lower operational costs because the walls of the apparatus do not require to be heated [16].

However, whether microwave-dried HILM can be used as a protein source for broilers is unclear. In the present study, SBM was substituted with microwave-dried HILM as a dietary protein source in broiler diets to evaluate the effects on carcass traits and breast meat quality, abdominal fat and leg meat FA composition, and heavy metal residues in chicken leg meat.

\section{Materials and Methods}

\subsection{Birds, Diets, and Experimental Design}

This study was approved by the Institutional Animal Care and Use Committee of the Rural Development Administration (No. NIAS-2020-497) and conducted at the poultry facility of the National Institute of Animal Science of South Korea. A total of 126 one-dayold male broiler chicks (Ross 308) were randomly assigned to three dietary treatments (six pens/treatment and seven birds/pen). Three experimental diets (Table 1) were formulated to meet or exceed the nutrient requirements for three phases [17]: starter (days 1-7), grower (days 7-21), and finisher (days 21-35). The control group (CON) was fed a diet based on corn and SBM; in experimental diets, SBM was substituted with 25 or $50 \%$ microwavedried HILM ( 25 and 50 HILM diets, respectively). Feed and water were available ad libitum throughout the trial. 
Table 1. Ingredients and chemical composition of the experimental diets (as-fed basis).

\begin{tabular}{|c|c|c|c|c|c|c|c|c|c|}
\hline \multirow[b]{2}{*}{ Item } & \multicolumn{3}{|c|}{ Starter } & \multicolumn{3}{|c|}{ Grower } & \multicolumn{3}{|c|}{ Finisher } \\
\hline & $\mathrm{CON}$ & $\begin{array}{c}25 \\
\text { HILM }\end{array}$ & $\begin{array}{c}50 \\
\text { HILM }\end{array}$ & $\mathrm{CON}$ & $\begin{array}{c}25 \\
\text { HILM }\end{array}$ & $\begin{array}{c}50 \\
\text { HILM }\end{array}$ & CON & $\begin{array}{c}25 \\
\text { HILM }\end{array}$ & $\begin{array}{c}50 \\
\text { HILM }\end{array}$ \\
\hline \multicolumn{10}{|l|}{ Ingredients, \% } \\
\hline Corn & 52.69 & 57.21 & 63.15 & 56.03 & 60.89 & 65.72 & 59.32 & 63.10 & 67.86 \\
\hline Soybean meal, $45.8 \%$ & 30.00 & 21.50 & 12.00 & 28.00 & 19.00 & 11.00 & 26.00 & 18.50 & 11.00 \\
\hline HILM & - & 7.50 & 15.00 & - & 7.00 & 14.00 & - & 6.50 & 13.00 \\
\hline Corn gluten meal & 8.00 & 7.00 & 6.00 & 7.00 & 6.00 & 5.00 & 6.00 & 5.00 & 4.00 \\
\hline Soybean oil & 4.50 & 3.00 & 1.00 & 4.50 & 3.50 & 1.50 & 4.50 & 3.50 & 1.50 \\
\hline Dicalcium phosphate & 1.95 & 1.80 & 1.60 & 1.80 & 1.70 & 1.60 & 1.60 & 1.56 & 1.54 \\
\hline Limestone & 1.50 & 0.70 & - & 1.40 & 0.70 & - & 1.40 & 0.70 & - \\
\hline L-lysine & 0.45 & 0.41 & 0.39 & 0.36 & 0.32 & 0.30 & 0.30 & 0.28 & 0.26 \\
\hline DL-methionine & 0.16 & 0.13 & 0.11 & 0.16 & 0.14 & 0.13 & 0.13 & 0.11 & 0.09 \\
\hline Salt & 0.25 & 0.25 & 0.25 & 0.25 & 0.25 & 0.25 & 0.25 & 0.25 & 0.25 \\
\hline Vitamin-mineral premix ${ }^{(1)}$ & 0.50 & 0.50 & 0.50 & 0.50 & 0.50 & 0.50 & 0.50 & 0.50 & 0.50 \\
\hline \multicolumn{10}{|l|}{ Calculated composition } \\
\hline $\mathrm{ME}, \mathrm{kcal} / \mathrm{kg}$ & 3119 & 3119 & 3119 & 3149 & 3149 & 3149 & 3177 & 3177 & 3177 \\
\hline Lysine, $\%$ & 1.47 & 1.47 & 1.47 & 1.33 & 1.33 & 1.33 & 1.21 & 1.21 & 1.21 \\
\hline Methionine, \% & 0.55 & 0.55 & 0.55 & 0.53 & 0.53 & 0.53 & 0.48 & 0.48 & 0.48 \\
\hline Calcium, \% & 0.97 & 0.97 & 0.97 & 0.91 & 0.91 & 0.91 & 0.85 & 0.85 & 0.85 \\
\hline Total phosphorus, \% & 0.79 & 0.79 & 0.79 & 0.75 & 0.75 & 0.75 & 0.70 & 0.70 & 0.70 \\
\hline Chitin, $\%$ & - & 0.43 & 0.86 & - & 0.40 & 0.80 & - & 0.37 & 0.74 \\
\hline \multicolumn{10}{|l|}{ Analyzed composition, $\%$} \\
\hline Crude protein & 23.23 & 23.67 & 23.60 & 21.96 & 21.76 & 22.08 & 19.53 & 19.97 & 19.80 \\
\hline NDF & 8.67 & 10.03 & 11.08 & 7.90 & 8.76 & 9.99 & 7.35 & 7.47 & 7.90 \\
\hline $\mathrm{ADF}$ & 3.36 & 4.03 & 4.38 & 3.73 & 3.67 & 4.02 & 3.10 & 3.59 & 3.74 \\
\hline ADF-linked protein & 0.42 & 0.91 & 1.02 & 0.68 & 0.82 & 1.00 & 0.48 & 0.79 & 1.09 \\
\hline Ash & 8.34 & 7.50 & 8.20 & 6.90 & 7.46 & 7.18 & 7.46 & 7.43 & 7.57 \\
\hline
\end{tabular}

CON, control diet; 25 and 50 HILM, HILM groups in which the soybean meal was replaced with 25 and 50\% HILM (Hermetia illucens larvae meal), respectively; ME, metabolizable energy; NDF, neutral detergent fiber; ADF, acid detergent fiber; ${ }^{(1)}$ Supplied per kilogram of diet: vitamin A 1,600,000 IU; vitamin $\mathrm{D}_{3}$ 300,000 IU; vitamin E $800 \mathrm{IU}$; vitamin $\mathrm{K}_{3} 132$ mg; vitamin B1 97 mg; vitamin B2 500 mg; vitamin B6 $200 \mathrm{mg}$; vitamin B12 $1.2 \mathrm{mg}$; nicotinic acid $2000 \mathrm{mg}$; pantothenic acid $800 \mathrm{mg}$; folic acid $60 \mathrm{mg}$; choline chloride 35,000 mg; Mn 12,000 mg; Zn 9000 mg; Fe 4000 mg; Cu 500 mg; I 250 mg; Co 100 mg; Se 50 mg.

Cleaned and dehydrated $\mathrm{HI}$ larvae were dried at $70-80{ }^{\circ} \mathrm{C}$ for $30 \mathrm{~min}$ using a microwave drying oven; subsequently, they were press-defatted at $45-48{ }^{\circ} \mathrm{C}$ using a cold press oil machine (NF-80; Karaerler, Ankara, Turkey). The defatted larvae were pulverized to mix with other ingredients.

The chemical compositions of the experimental diets (Table 1) and the major protein sources (Table 2), excluding chitin, were analyzed using Association of Official Analytical Communities (AOAC) methods [18]. Chitin concentrations in the experimental diets and the HILM were calculated as described by Marono et al. [19].

Table 2. Chemical composition (\%) of Hermetia illucens larvae meal (HILM) and soybean meal.

\begin{tabular}{|c|c|c|}
\hline Item & HILM & Soybean Meal \\
\hline Dry matter & 98.53 & 87.95 \\
\hline Crude protein & 61.24 & 45.76 \\
\hline Ether extract & 6.16 & 2.23 \\
\hline NDF & 20.34 & 10.14 \\
\hline $\mathrm{ADF}$ & 11.24 & 9.50 \\
\hline ADF-linked protein & 5.54 & 3.46 \\
\hline Ash & 14.98 & 5.52 \\
\hline Chitin (1) & 5.70 & - \\
\hline
\end{tabular}

NDF, neutral detergent fiber; $\mathrm{ADF}$, acid detergent fiber; ${ }^{(1)}$ Calculated data. 


\subsection{Slaughtering Procedure}

At the end of the study (35 days), 12 animals ( 2 birds per pen) from each experimental group were selected based on the average final live weight in each pen and slaughtered by cutting the carotid artery. The head, feet, and abdominal fat were removed from the plucked and eviscerated carcasses, and the carcass weight was recorded. The breast and leg meats were separated into the right and left sides and individually vacuum-sealed. The right breast meats were refrigerated at $4{ }^{\circ} \mathrm{C}$. The abdominal fat, left breasts, and leg meats were frozen at $-20^{\circ} \mathrm{C}$ until further analyses.

\subsection{Chemical Composition and Meat Quality of Breast Meat}

The proximate composition of freeze-dried left breast meat samples was analyzed using AOAC methods [18]. Refrigerated right breast meats were used to measure meat quality. The breast meat color was measured at 2 different sites (CR-20; Konica Minolta, Ramsey, NJ, USA) to determine the lightness $\left(\mathrm{L}^{*}\right)$, redness $\left(\mathrm{a}^{*}\right)$, and yellowness $\left(\mathrm{b}^{*}\right)$. The $\mathrm{pH}$ was measured at the same sites of the pectoralis major muscle using a $\mathrm{pH}$ meter (AM-7; Nihonseiki Kaisha Ltd., Tokyo, Japan). The meat samples were then vacuum-sealed in a plastic bag and cooked in a water bath at $80^{\circ} \mathrm{C}$ until the core temperature reached $75^{\circ} \mathrm{C}$, as described by Kim et al. [20]. The samples were cooled and dried before weighing to calculate the water-holding capacity (WHC, cooking loss). Using cooked meat core samples (diameter 0.5 inches), shear force was assessed with a Warner-Bratzler shear machine (Model 4465, Instron Corp., MA, USA).

\subsection{FA Profiles of Insect Meal, Soybean Meal, and Leg Meat}

Lipid was extracted from the samples using a solvent mixture of chloroform: methanol (2:1) as described by Folch et al. [21]. FA methyl esters were separated using a gas chromatography apparatus (Star 3600; Varian Technologies, Palo Alto, CA, USA) equipped with an Omegawax 205 fused-silica bond capillary column $(30 \mathrm{~m} \times 0.32 \mathrm{~mm} \times 0.25 \mu \mathrm{m}$ film thickness) from the transmethylated samples using a methanolic solution of $\mathrm{H}_{2} \mathrm{SO}_{4}$ $(4 \%)$. The oven temperature was held at $50{ }^{\circ} \mathrm{C}$ for $1 \mathrm{~min}$ and then raised to $200{ }^{\circ} \mathrm{C}$ at a rate of $25^{\circ} \mathrm{C} / \mathrm{min}$. Aliquot of $2 \mu \mathrm{L}$ of the samples were injected into the injection ports, and the temperatures of the injector and detector were 250 and $260{ }^{\circ} \mathrm{C}$, respectively. Nitrogen was used as the carrier gas at a flow rate of $1 \mathrm{~mL} / \mathrm{min}$. The FA composition of the samples was expressed as the percentage (\%) of the total detected FA methyl esters.

\subsection{Heavy Metal Analysis}

The HILM and leg meat samples $(0.5 \mathrm{~g})$ were mixed with nitric acid and hydrogen peroxide for microwave digestion. The resulting solutions were filtered with filter paper and transferred to acid-cleaned tubes. These solutions were diluted with deionized water. The concentrations of heavy metals in the samples were determined by inductively coupled plasma-mass spectrometry (Agilent 7700x; Agilent Technologies, Santa Clara, CA, USA).

\subsection{Statistical Analysis}

Statistical analysis of the data was performed using the GLM procedure in SAS version 9.4 (SAS, Inc., Cary, NC, USA) [22]. Differences among treatments were determined by Tukey's multiple comparison test [22]. An individual bird was considered as an experimental unit for statistical analysis ( $\mathrm{n}=12$ per treatment; two birds per pen). The results are presented as the mean \pm standard error of the means. Significance and tendency were defined as $p<0.05$ and $0.05<p<0.10$, respectively.

\section{Results}

\subsection{Chemical Composition and FA Profile of Insect Meal and SBM}

The chemical compositions of HILM and SBM are summarized in Table 2. HILM contained more crude protein compared to SBM. The FA profiles differed between groups, as shown in Table 3; HILM contains the SFA more than 50\%, whereas the FA profile of 
SBM was composed of the PUFA more than half. However, the monounsaturated fatty acid (MUFA) content was similar between the HILM and SBM groups.

Table 3. Fatty acid profile (\% of total fatty acid methyl esters) of Hermetia illucens larvae meal (HILM) and soybean meal.

\begin{tabular}{ccc}
\hline Item & HILM & Soybean Meal \\
\hline Fatty acids & & \\
C10:0 & 1.62 & 0.02 \\
C12:0 (Lauric) & 29.69 & 0.15 \\
C14:0 (Myristic) & 4.39 & 0.46 \\
C16:0 (Palmitic) & 15.85 & 15.87 \\
C17:0 & 0.23 & 0.18 \\
C18:0 (Stearic) & 3.37 & 6.21 \\
Total SFA & 55.15 & 22.89 \\
C14:1 & 0.10 & 0.06 \\
C16:1 $n$-7 (Palmitoleic) & 2.67 & 0.69 \\
C17:1 & 0.23 & 0.09 \\
C18:1 $n$-9 (Oleic) & 19.67 & 22.39 \\
C20:1 $n-9$ (Eiocosenoic) & 0.20 & 0.21 \\
Total MUFA & 22.87 & 23.44 \\
C18:2 $n-6$ (Linoleic) & 15.74 & 46.19 \\
C18:3 $n$-3 $(\alpha$-Linolenic) & 2.58 & 5.35 \\
C20:2 $n-6$ & 0.20 & 0.19 \\
C20:3 $n-3$ & 0.03 & 0.03 \\
C20:4 $n$ - 6 (Arachidonic) & 0.28 & 0.14 \\
Total PUFA & 18.80 & 51.87 \\
UFA $/$ SFA & 0.76 & 3.29 \\
$n-6$ & 16.22 & 46.52 \\
$n-3$ & 2.61 & 5.38 \\
$n-6 / n-3$ & 6.21 & 8.65
\end{tabular}

SFA, saturated fatty acid; MUFA, monounsaturated fatty acid; PUFA, polyunsaturated fatty acid; UFA, unsaturated fatty acid.

\subsection{Carcass Characteristics, Quality Parameters, and Chemical Composition of Breast Meat}

As presented in Table 4 , the live weight (LW) was significantly decreased $(p<0.001)$ in the 50 HILM group compared to the CON and 25 HILM groups. However, no significant difference was observed in the LW between the CON and 25 HILM groups. The carcass weight and percentage of the carcass $(\% \mathrm{LW})$ in the 50 HILM group were significantly lower $(p<0.001)$ than in the other groups. No significant differences were found in meat quality parameters, except for the $\mathrm{pH}$, redness $\left(\mathrm{a}^{*}\right)$ value, and WHC (Table 4). Dietary HILM supplementation increased $(p<0.05)$ the $\mathrm{pH}$, redness, and WHC but did not significantly influence the chemical composition of the breast meat.

Table 4. Effect of dietary Hermetia illucens larvae meal (HILM) inclusion level on the carcass and breast meat traits of broiler chickens.

\begin{tabular}{|c|c|c|c|c|c|}
\hline \multirow{2}{*}{ Item } & \multicolumn{3}{|c|}{ Dietary Treatment } & \multirow{2}{*}{ SEM } & \multirow{2}{*}{$p$-Value } \\
\hline & $\mathrm{CON}$ & 25 HILM & 50 HILM & & \\
\hline Live weight (LW), $\mathrm{kg}$ & $1.80^{\mathrm{a}}$ & $1.76^{\mathrm{a}}$ & $1.49^{b}$ & 0.04 & 0.0004 \\
\hline Carcass weight, $\mathrm{kg}$ & $1.27^{\mathrm{a}}$ & $1.25^{\mathrm{a}}$ & $1.03^{b}$ & 0.03 & 0.0003 \\
\hline Carcass weight, \% LW & $70.67^{\mathrm{a}}$ & $71.16^{\mathrm{a}}$ & $68.91^{\mathrm{b}}$ & 0.53 & 0.0003 \\
\hline $\mathrm{pH}$ & $5.75^{\mathrm{b}}$ & $5.77^{a b}$ & $5.87^{\mathrm{a}}$ & 0.03 & 0.0409 \\
\hline \multicolumn{6}{|l|}{ Color } \\
\hline Lightness, L* & 54.79 & 55.52 & 55.21 & 1.03 & 0.8815 \\
\hline Redness, $\mathrm{a}^{*}$ & $3.52^{b}$ & $5.16^{\mathrm{a}}$ & $5.13^{\mathrm{a}}$ & 0.34 & 0.0023 \\
\hline Yellowness, $b^{*}$ & 8.11 & 8.87 & 8.72 & 0.78 & 0.7661 \\
\hline Cooking loss, $\%$ & 23.71 & 23.15 & 22.60 & 0.74 & 0.6207 \\
\hline WHC, $\%$ & $60.39 \mathrm{ab}$ & $60.05^{b}$ & $62.24^{\mathrm{a}}$ & 0.57 & 0.0422 \\
\hline Shear force, $\mathrm{kg} / 0.5 \mathrm{inch}^{2}$ & 2.48 & 2.42 & 2.34 & 0.19 & 0.9017 \\
\hline Moisture, $\%$ & 75.75 & 75.85 & 76.27 & 0.25 & 0.3796 \\
\hline Protein, \% & 22.43 & 22.27 & 22.21 & 0.24 & 0.8225 \\
\hline Lipid, \% & 0.95 & 1.16 & 0.87 & 0.11 & 0.2024 \\
\hline Ash, \% & 1.09 & 1.08 & 1.02 & 0.02 & 0.1335 \\
\hline
\end{tabular}

$\overline{\mathrm{CON}}$, control diet; 25 and 50 HILM, HILM groups in which the soybean meal was replaced with 25 and $50 \%$ HILM, respectively; SEM, standard error of the means; WHC, water-holding capacity; ${ }^{\mathrm{a}, \mathrm{b}}$ Values with different superscripts in the same row are significantly different $(p<0.05)$. 


\subsection{FA Profile of Abdominal Fat and Leg Meat}

The effects of the experimental diets on the FA profile of abdominal fat are presented in Table 5 . The proportion of SFAs, such as myristic and palmitic acid, was significantly increased, whereas PUFAs, such as linoleic, $\alpha$-linolenic, and arachidonic acid, were decreased with increasing HILM levels $(p<0.01)$. The total MUFA content was also increased $(p<0.0001)$ by dietary HILM supplementation. A similar pattern was observed in the FA profile of leg meat (Table 6). However, dietary HILM supplementation did not alter the FA profile of the leg meat, contrasting the results for abdominal fat.

Table 5. Effect of dietary Hermetia illucens larvae meal (HILM) inclusion level on the fatty acid profile in abdominal fat of broiler chickens.

\begin{tabular}{|c|c|c|c|c|c|}
\hline \multirow{2}{*}{ Item } & \multicolumn{3}{|c|}{ Dietary Treatment } & \multirow{2}{*}{ SEM } & \multirow{2}{*}{$p$-Value } \\
\hline & $\mathrm{CON}$ & 25 HILM & 50 HILM & & \\
\hline \multicolumn{6}{|l|}{ Fatty acids } \\
\hline C14:0 (Myristic) & $0.43^{c}$ & $0.68^{\mathrm{b}}$ & $0.85^{\mathrm{a}}$ & 0.03 & $<0.0001$ \\
\hline C16:0 (Palmitic) & $20.84^{\mathrm{c}}$ & $23.25^{b}$ & $25.44^{\mathrm{a}}$ & 0.53 & $<0.0001$ \\
\hline C18:0 (Stearic) & 7.31 & 6.79 & 6.53 & 0.25 & 0.1133 \\
\hline Total SFA & $28.57^{\mathrm{c}}$ & $30.72^{b}$ & $32.83^{\mathrm{a}}$ & 0.54 & 0.0002 \\
\hline C16:1 n-7 (Palmitoleic) & $4.12^{c}$ & $5.46^{\mathrm{b}}$ & $6.88^{\mathrm{a}}$ & 0.35 & 0.0002 \\
\hline C18:1 n-9 (Oleic) & $38.57^{b}$ & $39.37^{b}$ & $42.44^{\mathrm{a}}$ & 0.52 & 0.0002 \\
\hline C20:1 n-9 (Eicosenoic) & 0.38 & 0.36 & 0.38 & 0.01 & 0.2764 \\
\hline Total MUFA & $43.06^{b}$ & $45.19^{b}$ & $49.70^{a}$ & 0.76 & $<0.0001$ \\
\hline C18:2 n-6 (Linoleic) & $26.28^{\mathrm{a}}$ & $22.28^{b}$ & $16.27^{c}$ & 0.98 & $<0.0001$ \\
\hline C18:3 n-6 ( $\gamma$-Linolenic) & 0.21 & 0.20 & 0.17 & 0.01 & 0.1820 \\
\hline C18:3 n-3 ( $\alpha$-Linolenic) & $1.61^{\mathrm{a}}$ & $1.43^{\mathrm{a}}$ & $0.89^{b}$ & 0.07 & $<0.0001$ \\
\hline C20:4 n-6 (Arachidonic) & $0.26^{\mathrm{a}}$ & $0.18^{\mathrm{ab}}$ & $0.14^{\mathrm{b}}$ & 0.02 & 0.0047 \\
\hline Total PUFA & $28.36^{\mathrm{a}}$ & $24.09^{b}$ & $17.47^{c}$ & 1.07 & $<0.0001$ \\
\hline UFA/SFA & $2.50^{\mathrm{a}}$ & $2.26^{\mathrm{b}}$ & $2.05^{c}$ & 0.06 & 0.0001 \\
\hline n-6 & $26.75^{a}$ & $22.66^{\mathrm{b}}$ & $16.58^{c}$ & 1.00 & $<0.0001$ \\
\hline$n-3$ & $1.61^{\mathrm{a}}$ & $1.43^{\mathrm{a}}$ & $0.89^{b}$ & 0.07 & $<0.0001$ \\
\hline$n-6 / n-3$ & $16.63^{b}$ & $16.00^{b}$ & $18.55^{\mathrm{a}}$ & 0.26 & $<0.0001$ \\
\hline
\end{tabular}

CON, control diet; 25 and 50 HILM, HILM groups in which the soybean meal was replaced with 25 and $50 \%$ HILM, respectively; SEM, standard error of the means; SFA, saturated fatty acid; MUFA, monounsaturated fatty acid; PUFA, polyunsaturated fatty acid; UFA, unsaturated fatty acid; ${ }^{a, b, c}$ Values with different superscripts in the same row are significantly different $(p<0.01)$.

Table 6. Effect of dietary Hermetia illucens larvae meal (HILM) inclusion level on the fatty acid profile in leg meat of broiler chickens.

\begin{tabular}{|c|c|c|c|c|c|}
\hline \multirow{2}{*}{ Item } & \multicolumn{3}{|c|}{ Dietary Treatment } & \multirow{2}{*}{ SEM } & \multirow{2}{*}{$p$-Value } \\
\hline & $\mathrm{CON}$ & 25 HILM & 50 HILM & & \\
\hline \multicolumn{6}{|l|}{ Fatty acids } \\
\hline C12:0 (Lauric) & 0.63 & 0.89 & 0.88 & 0.16 & 0.470 \\
\hline C14:0 (Myristic) & 0.67 & 0.77 & 0.77 & 0.06 & 0.463 \\
\hline C16:0 (Palmitic) & 22.09 & 23.56 & 23.48 & 0.65 & 0.229 \\
\hline C18:0 (Stearic) & 7.19 & 6.98 & 7.41 & 0.24 & 0.496 \\
\hline Total SFA & 30.59 & 32.20 & 32.54 & 0.72 & 0.164 \\
\hline C16:1 n-7 (Palmitoleic) & 4.75 & 5.30 & 5.33 & 0.41 & 0.549 \\
\hline C18:1 n-9 (Oleic) & 36.23 & 36.35 & 36.68 & 0.67 & 0.904 \\
\hline C20:1 n-9 (Eicosenoic) & 1.69 & 1.44 & 1.33 & 0.10 & 0.076 \\
\hline Total MUFA & 42.67 & 43.09 & 43.35 & 0.97 & 0.895 \\
\hline C18:2 n-6 (Linoleic) & 23.23 & 21.50 & 20.60 & 1.22 & 0.355 \\
\hline C18:3 n-6 ( $\gamma$-Linolenic) & 0.19 & 0.20 & 0.19 & 0.01 & 0.729 \\
\hline C18:3 n-3 ( $\alpha$-Linolenic) & 0.27 & 0.26 & 0.31 & 0.01 & 0.081 \\
\hline C20:4 n-6 (Arachidonic) & 0.73 & 0.70 & 0.75 & 0.12 & 0.951 \\
\hline C22:6 n-3 (Docosahexaenoic) & 0.10 & 0.10 & 0.09 & 0.02 & 0.883 \\
\hline Total PUFA & 24.52 & 22.73 & 21.94 & 1.32 & 0.413 \\
\hline UFA/SFA & 2.22 & 2.05 & 2.03 & 0.07 & 0.121 \\
\hline n-6 & 24.15 & 22.40 & 21.54 & 1.30 & 0.404 \\
\hline$n-3$ & 0.37 & 0.36 & 0.39 & 0.28 & 0.726 \\
\hline$n-6 / n-3$ & 64.86 & 63.49 & 60.40 & 4.07 & 0.772 \\
\hline
\end{tabular}

CON, control diet; 25 and 50 HILM, HILM groups in which the soybean meal was replaced with 25 and $50 \%$ HILM, respectively; SEM, standard error of the means; SFA, saturated fatty acid; MUFA, monounsaturated fatty acid; PUFA, polyunsaturated fatty acid; UFA, unsaturated fatty acid.

\subsection{Essential Elements and Undesirable Substances in Insect Meal and Leg Meat}

The concentrations of essential elements and undesirable substances in the HILM and leg meat are summarized in Tables 7 and 8. The concentrations of undesirable substances, 
such as fluorine, arsenic, lead, mercury, and cadmium, in the HILM, were below the permissible limits for animal feeds according to the standards reported by the European Commission [23]. The concentrations of lead and cadmium were also under the permissible limits for chicken meats [24]. Dietary HILM increased the concentrations of selenium and zinc in the leg meat, for which permissible limits did not apply.

Table 7. Essential elements and undesirable substances $(\mathrm{mg} / \mathrm{kg})$ in Hermetia illucens larvae meal (HILM).

\begin{tabular}{ccc}
\hline Item & HILM & Permissible Limit (EC, 2002) \\
\hline Essential elements & & \\
Mg & 5600 & NA \\
$\mathrm{S}$ & 562.24 & $\mathrm{NA}$ \\
Essential trace elements & & \\
$\mathrm{Fe}$ & 560.90 & $\mathrm{NA}$ \\
$\mathrm{Cu}$ & 456.34 & $\mathrm{NA}$ \\
$\mathrm{Zn}$ & 142.15 & $\mathrm{NA}$ \\
$\mathrm{I}$ & $\mathrm{ND}$ & $\mathrm{NA}$ \\
$\mathrm{Cr}$ & 59.06 & $\mathrm{NA}$ \\
$\mathrm{Co}$ & 4.51 & $\mathrm{NA}$ \\
$\mathrm{Se}$ & 0.48 & $\mathrm{NA}$ \\
$\mathrm{Mn}$ & 101.08 & $\mathrm{NA}$ \\
$\mathrm{Al}$ & & \\
$\mathrm{F}$ & 3.25 & $\mathrm{NA}$ \\
$\mathrm{As}$ & 0.01 & 150 \\
$\mathrm{~Pb}$ & 0.01 & 2 \\
$\mathrm{Hg}$ & 0.01 & 10 \\
$\mathrm{Cd}$ & $<0.01$ & 0.1 \\
Undesirable substances & $\mathrm{ND}$ & 2 \\
\hline
\end{tabular}

Table 8. Essential elements and undesirable substances $(\mathrm{mg} / \mathrm{kg})$ in leg meat of broiler chickens fed Hermetia illucens larvae meal (HILM).

\begin{tabular}{|c|c|c|c|c|c|c|}
\hline \multirow{2}{*}{ Item } & \multicolumn{3}{|c|}{ Dietary Treatment } & \multirow{2}{*}{ SEM } & \multirow{2}{*}{$p$-Value } & \multirow{2}{*}{ Permissible Limit (EC, 2006) } \\
\hline & $\mathrm{CON}$ & 25 HILM & 50 HILM & & & \\
\hline \multicolumn{7}{|c|}{ Essential elements } \\
\hline $\mathrm{Mg}$ & 233.60 & 232.74 & 222.45 & 4.24 & 0.191 & NA \\
\hline $\mathrm{S}$ & $20.73^{b}$ & $25.19^{b}$ & $36.53^{\mathrm{a}}$ & 1.80 & $<0.0001$ & NA \\
\hline \multicolumn{7}{|c|}{ Essential trace elements } \\
\hline $\mathrm{Fe}$ & 7.72 & 8.27 & 9.29 & 0.43 & 0.070 & NA \\
\hline $\mathrm{Cu}$ & 0.49 & 0.32 & 0.10 & 0.13 & 0.160 & NA \\
\hline $\mathrm{Zn}$ & $11.65^{b}$ & $12.00 \mathrm{ab}$ & $13.43^{\mathrm{a}}$ & 0.44 & 0.035 & NA \\
\hline $\mathrm{I}$ & 0.06 & 0.05 & 0.07 & 0.01 & 0.131 & NA \\
\hline $\mathrm{Cr}$ & $<0.10$ & $<0.10$ & $<0.10$ & - & - & NA \\
\hline Co & $<0.10$ & $<0.10$ & $<0.10$ & - & - & NA \\
\hline Se & $<0.10$ & $<0.10$ & $<0.10$ & - & - & NA \\
\hline $\mathrm{Mn}$ & $<0.10$ & $<0.10$ & $<0.10$ & - & - & NA \\
\hline \multicolumn{7}{|c|}{ Undesirable substances } \\
\hline $\mathrm{Al}$ & 6.48 & 4.45 & 2.62 & 1.65 & 0.319 & NA \\
\hline $\mathrm{F}$ & 0.04 & 0.05 & 0.05 & 0.01 & 0.568 & NA \\
\hline As & $<0.01$ & $<0.01$ & $<0.01$ & - & - & NA \\
\hline $\mathrm{Pb}$ & $<0.01$ & $<0.01$ & $<0.01$ & - & - & 0.10 \\
\hline $\mathrm{Hg}$ & $<0.01$ & $<0.01$ & $<0.01$ & - & - & NA \\
\hline $\mathrm{Cd}$ & $<0.01$ & $<0.01$ & $<0.01$ & - & - & 0.05 \\
\hline
\end{tabular}

CON, control diet; 25 and 50 HILM, HILM groups in which the soybean meal was replaced with 25 and $50 \%$ HILM, respectively; SEM, standard error of the means; EC, European Commission; NA, not applicable: ${ }^{a, b}$ Values with different superscripts in the same row are significantly different $(p<0.05)$. 


\section{Discussion}

Drying processes have extremely important effects on the nutritional value of food products. The microwave drying method is commonly used for food preservation and is suitable for insect processing in terms of microbial stabilization by effectively removing moisture [25]. However, the microwave drying method adversely affects the chemical composition of food by polymerizing protein particles to make them more compact with larger diameters [15]. Such chemical structural change can decrease digestibility by impairing dissolution by digestive enzymes when compared to the conventional drying methods $[15,26]$. Few studies have evaluated the effects of microwave-dried HILM on meat quality traits and safety. In the present study, we used a press-defatted HILM derived from larvae reared on food waste. The nutrient composition of HI larvae depends on the substrates; however, the protein content of microwave-dried HILM was superior to that of SBM [2]. HILM and SBM showed opposite FA profiles; HILM was rich in SFA, whereas SBM was rich in PUFA. Thus, we predicted that dietary microwave-dried HILM would affect carcass traits and the FA composition of the abdominal fat and meat.

In the present study, increasing the level of substitution of SBM with HILM in the broiler diet negatively affected carcass traits. The decreased live and carcass weights of broilers in the 50 HILM group could be attributed to the chitin in the exoskeleton of HI larvae [13]. It was reported that chitin can negatively affect protein digestibility [19]. Acid detergent fiber (ADF) fractions were analyzed to estimate the chitin contents in the HILM and the diets. The amount of the chitin in the HILM used as feed in the present study was $5.70 \%$, calculated as follows: chitin $(\%)=$ ash free ADF (\%) - ADF-linked protein $(\%)$, according to Marono et al. [19]. In the present trial, average daily feed intakes in the CON, 25 HILM, and 50 HILM groups were 70.30, 70.69, and $62.07 \mathrm{~g} / \mathrm{d}$, respectively. Therefore, the 25 and 50 HILM groups ingested approximately 0.28 and $0.50 \mathrm{~g} / \mathrm{d}$ of chitin, respectively, considering the inclusion levels of HILM in the diets. According to Bovera et al. [4], laying hens (sixteen weeks old) that ingested approximately $0.47 \mathrm{~g} / \mathrm{d}$ of chitin had lower protein digestibility than those fed on SBM-based diets, and it linearly decreased with an increase in inclusion level of insect meal in the diet. Chitin, which cannot be digested, and the microwave drying process of HILM may explain these lowered carcass traits $[4,13]$. However, the 25 HILM group showed satisfactory results for the carcass weight and rate compared to the 50 HILM group. This result agrees with that of a previous study showing that the carcass weight was linearly decreased with the inclusion levels $(5,10$, and $15 \%)$ of HILM and drastically decreased by high inclusion level (15\%) of HILM [9]. Therefore, including a low level of HILM in the broiler diet may maintain the carcass traits.

In general, the $\mathrm{pH}$ of meat is correlated with the WHC, and changes in the $\mathrm{pH}$ of breast meat in broilers fed HILM were related to the carcass weight. Therefore, the increased WHC was influenced by the meat $\mathrm{pH}$ [27]. Additionally, the $\mathrm{pH}$ of meat was negatively correlated with carcass weight, and the decreased carcass weight of broilers fed HILM affected the $\mathrm{pH}$ of breast meat $[28,29]$. Although the $\mathrm{pH}$ of breast meat was increased by dietary HILM, the $\mathrm{pH}$ and $\mathrm{L}^{*}$ values of breast meat were in normal ranges $[30,31]$. Bovera et al. [32] also reported that the use of Tenebrio molitor larvae meal in a broiler diet increased the breast meat $\mathrm{pH}$, whereas inclusion of HILM did not affect the $\mathrm{pH}$ regardless of the carcass weight loss [9]. Additionally, the substitution of HILM in a broiler quail diet decreased the $\mathrm{pH}$ in breast meat without negatively affecting the carcass weight and dressing percentage [10]. They suggested that the difference in $\mathrm{pH}$ occurred because of differences in the muscle glycogen content. These conflicting results for the $\mathrm{pH}$ of breast meat in broilers fed insect meal should be interpreted with caution.

According to the meat quality parameters, HILM inclusion had a satisfactory effect on the chicken breast meat. The increase in the $\mathrm{pH}$ and WHC did not affect cooking loss or shear force. This result indicates that chicken breast meat from broilers fed HILM can contribute to consumer acceptance of the meat [29]. However, when HILM was included in the broiler diets, a noticeable increase in redness was observed, which agrees with a previous study [9]. They also showed some conflicting results; yellowness was decreased 
by dietary HILM. In contrast, redness was decreased and yellowness was not affected in the breast meat of broiler quails [10]. The reason for the higher level of redness in breast meat in the 25 and 50 HILM groups compared with those in the CON group are unclear, although different species and breeds may affect the meat quality [33]. Additionally, a pigment derived from HILM and HI larvae oil may have affected the meat color and egg yolk color $[9,11]$.

As expected, the FA profile in abdominal fat changed in line with the pattern of that in HILM, which contained higher levels of SFAs and lower levels of PUFAs than SBM. However, dietary HILM showed weaker effects on the FA profile of leg meat. Similarly, previous studies showed that the FA profile of breast meat from broiler chicken and quail was affected by the high SFA content in HILM $[9,10]$. In the present study, the unchanged FA composition in leg meat was attributed to the relatively lower SFA content in microwave-dried HILM when compared to the levels in previous studies. Moreover, the FA composition of fat tissues (e.g., abdominal and subcutaneous) is more representative of the dietary FA composition than that in muscle tissue such as breast and leg muscles of broiler chickens [34]. Particularly, it was reported that broilers fed PUFA had lower abdominal fat levels, with more fat deposited in the muscle because of the different roles of SFA and PUFA in the body tissues [12]. This explains the significant difference in the FA composition of abdominal fat but not in leg meat. In a previous study, it was reported that the FA profile of abdominal fat was not changed in broilers fed Tenebrio molitor larvae meal [35]. The different FA concentrations of the Tenebrio molitor and HI can be attributed to the conflicting result; UFA concentrations are higher in mealworms than HI larvae [36].

The safety of chicken leg meat from broilers fed HILM must be verified to determine its heavy metal concentrations, ensuring that healthy chickens were provided to consumers and to improve consumer perception. Heavy metals accumulated in all development stages (e.g., larvae, prepupae, and adults); heavy metal concentrations in the larvae were increased with metal concentrations in the food [37]. The concentrations of hazardous heavy metals such as fluorine, arsenic, lead, mercury, and cadmium in HILM were below the European Union limits [23]. Moniello et al. [38] also reported concentrations of the toxic elements in insect meal and experimental diets in which SBM was replaced with insect meal (inclusion level in the diets: 7.3 and 14.6\%, respectively). The concentrations of the toxic elements in the microwave-dried HILM were comparable or lower than those in a previous study [39], demonstrating that the concentrations of the toxic elements were negligible [39]. Our results also suggest that the microwave-dried HILM is suitable as an animal feed ingredient with regard to safety. Moreover, the concentrations of lead and cadmium in the leg meat did not exceed allowable levels [24]. In this study, the contents of zinc and sulfur in leg meat were increased by dietary HILM but the level of the zinc was in a normal range and not defined by the European Union [39]; the allowable level of sulfur is also not legislated [24]. In general, sulfur is provided by sulfur-containing amino acids (e.g., methionine and cysteine) in humans, and most people may not ingest sufficient amounts of sulfur [40]. These results suggest that HI larvae fed food waste was not contaminated, with no negative effects on chicken meat from broilers fed HILM.

\section{Conclusions}

We demonstrated the effects of microwave-dried HILM as a potential feed ingredient in broiler diets. The difference in the FA profiles of abdominal fat between dietary treatments was ascribed to the different FA profiles of HILM and SBM. The FA profile showed lower differences in chicken meat than in abdominal fat, and the breast meat showed good quality. Dietary HILM did not negatively affect the heavy metal contents in the chicken leg meat. Our findings suggest that SBM can be substituted at less than $25 \%$ with HILM in the broiler diets in terms of carcass weight. Further studies are needed to examine the utilization efficiency and improve the manufacturing process of HILM. 
Author Contributions: Conceptualization, B.K., H.T.B., and S.Y.J.; methodology, B.K., H.R.K., S.L., Y.-C.B., J.Y.J., and S.H.P.; software, Y.-C.B.; investigation, J.Y.J.; data curation, B.K. and S.H.P.; writingoriginal draft preparation, B.K.; writing - review and editing, S.Y.J. and S.H.P.; funding acquisition, S.H.P. All authors have read and agreed to the published version of the manuscript.

Funding: This study was carried out with the support of the "Cooperative Research Program for Agriculture Science and Technology Development (Project No. PJ01456002)” Rural Development Administration, Republic of Korea.

Institutional Review Board Statement: The study was conducted according to the guidelines of the Declaration of Helsinki and approved by the Institutional Review Board (or Ethics Committee) of the Rural Development Administration, Republic of Korea (protocol code NIAS-2020-497 and 18 August 2020).

Informed Consent Statement: Not applicable.

Data Availability Statement: The data presented in this study are available on reasonable request from the corresponding authors.

Acknowledgments: This study was supported by the 2021 RDA Fellowship Program of the National Institute of Animal Science, Rural Development Administration, Republic of Korea.

Conflicts of Interest: The authors declare no conflict of interest.

\section{References}

1. Surendra, K.C.; Olivier, R.; Tomberlin, J.K.; Jha, R.; Khanal, S.K. Bioconversion of organic wastes into biodiesel and animal feed via insect farming. Renew. Energy 2016, 98, 197-202. [CrossRef]

2. $\quad$ Spranghers, T.; Ottoboni, M.; Klootwijk, C.; Ovyn, A.; Deboosere, S.; De Meulenaer, B.; Michiels, J.; Eeckhout, M.; De Clercq, P.; De Smet, S. Nutritional composition of black soldier fly (Hermetia illucens) prepupae reared on different organic waste substrates. J. Sci. Food Agric. 2017, 97, 2594-2600. [CrossRef] [PubMed]

3. Wise, T.A. Can we feed the world in 2050? A scoping paper to assess the evidence. Glob. Dev. Environ. Inst. 2013, 13, 1-38. [CrossRef]

4. Bovera, F.; Loponte, R.; Pero, M.E.; Cutrignelli, M.I.; Calabrò, S.; Musco, N.; Vassalotti, G.; Panettieri, V.; Lombardi, P.; Piccolo, G.; et al. Laying performance, blood profiles, nutrient digestibility and inner organs traits of hens fed an insect meal from Hermetia illucens larvae. Res. Vet. Sci. 2018, 120, 86-93. [CrossRef] [PubMed]

5. Cullere, M.; Tasoniero, G.; Giaccone, V.; Acuti, G.; Marangon, A.; Dalle Zotte, A. Black soldier fly as dietary protein source for broiler quails: Meat proximate composition, fatty acid and amino acid profile, oxidative status and sensory traits. Animal 2018, 12, 640-647. [CrossRef]

6. Lock, E.R.; Arsiwalla, T.; Waagbø, R. Insect larvae meal as an alternative source of nutrients in the diet of Atlantic salmon (Salmo salar) postsmolt. Aquac. Nutr. 2016, 22, 1202-1213. [CrossRef]

7. Bava, L.; Jucker, C.; Gislon, G.; Lupi, D.; Savoldelli, S.; Zucali, M.; Colombini, S. Rearing of Hermetia illucens on different organic By-Products: Influence on growth, waste reduction, and environmental impact. Animals 2019, 9, 289. [CrossRef]

8. Biancarosa, I.; Liland, N.S.; Biemans, D.; Araujo, P.; Bruckner, C.G.; Waagbø, R.; Torstensen, B.E.; Lock, E.J.; Amlund, H. Uptake of heavy metals and arsenic in black soldier fly (Hermetia illucens) larvae grown on seaweed-enriched media. J. Sci. Food Agric. 2018, 98, 2176-2183. [CrossRef] [PubMed]

9. Schiavone, A.; Dabbou, S.; Petracci, M.; Zampiga, M.; Sirri, F.; Biasato, I.; Gai, F.; Gasco, L. Black soldier fly defatted meal as a dietary protein source for broiler chickens: Effects on carcass traits, breast meat quality and safety. Animal 2019, 13, 2397-2405. [CrossRef]

10. Cullere, M.; Tasoniero, G.; Giaccone, V.; Miotti-Scapin, R.; Claeys, E.; De Smet, S.; Dalle Zotte, A. Black soldier fly as dietary protein source for broiler quails: Apparent digestibility, excreta microbial load, feed choice, performance, carcass and meat traits. Animal 2016, 10, 1923-1930. [CrossRef] [PubMed]

11. Dalle Zotte, A.D.; Singh, Y.; Michiels, J.; Cullere, M. Black soldier fly (Hermetia illucens) as dietary source for laying quails: Live performance, and egg physico-chemical quality, sensory profile and storage stability. Animals 2019, 9, 115. [CrossRef] [PubMed]

12. Crespo, N.; Esteve-Garcia, E. Dietary fatty acid profile modifies abdominal fat deposition in broiler chickens. Poult. Sci. 2001, 80, 71-78. [CrossRef] [PubMed]

13. Longvah, T.; Mangthya, K.; Ramulu, P. Nutrient composition and protein quality evaluation of eri silkworm (Samia ricinii) prepupae and pupae. Food Chem. 2011, 128, 400-403. [CrossRef] [PubMed]

14. Dabbou, S.; Gai, F.; Biasato, I.; Capucchio, M.T.; Biasibetti, E.; Dezzutto, D.; Meneguz, M.; Plachà, I.; Gasco, L.; Schiavone, A. Black soldier fly defatted meal as a dietary protein source for broiler chickens: Effects on growth performance, blood traits, gut morphology and histological features. J. Anim. Sci. Biotechnol. 2018, 9, 49. [CrossRef] 
15. Huang, C.; Feng, W.; Xiong, J.; Wang, T.; Wang, W.; Wang, C.; Yang, F. Impact of drying method on the nutritional value of the edible insect protein from black soldier fly (Hermetia illucens L.) larvae: Amino acid composition, nutritional value evaluation, in vitro digestibility, and thermal properties. Eur. Food Res. Technol. 2019, 245, 11-21. [CrossRef]

16. Khodifad, B.C.; Dhamsaniya, N.K. Drying of food materials by microwave energy-A review. Int. J. Curr. Microbiol. App. Sci. 2020, 9, 1950-1973. [CrossRef]

17. Korean Feeding Standard for Poultry. In Nutrient Requirements of Poultry, 3rd ed.; National Institute of Animal Science: Wanju, Korea, 2017.

18. Association of Official Analytical Communities (AOAC). Official Methods of Analysis, 18th ed.; Association of Official Analytical Chemists: Arlington, VA, USA, 2005.

19. Marono, S.; Piccolo, G.; Loponte, R.; Di Meo, C.; Attia, Y.A.; Nizza, A.; Bovera, F. In vitro crude protein digestibility of Tenebrio molitor and Hermetia illucens insect meals and its correlation with chemical composition traits. Ital. J. Anim. Sci. 2015, 14, 338-343. [CrossRef]

20. Kim, B.; Bang, H.T.; Kim, K.H.; Kim, M.J.; Jeong, J.Y.; Chun, J.L.; Ji, S.Y. Evaluation of black soldier fly larvae oil as a dietary fat source in broiler chicken diets. J. Anim. Sci. Technol. 2020, 62, 187-197. [CrossRef] [PubMed]

21. Folch, J.; Lees, M.; Sloane Stanley, G.H. A simple method for the isolation and purification of total lipids from animal tissues. J. Biol. Chem. 1957, 226, 497-509. [CrossRef]

22. Statistical Analysis Software for Windows 2009; Statistics Version 9.4; SAS Institute: Cary, NC, USA, 2009.

23. European Commission Council Directive (EC) 2002/32/EC of 7 May 2002 on undesirable substances in animal feed. Off. J. Eur. Commun. 2002, L140, 10-21.

24. European Commission Council Directive (EC) 1881/2006 of 19 December 2006 setting maximum levels for certain contaminants in foodstuffs. Off. J. Eur. Commun. 2006, L364, 5-24.

25. Lenaerts, S.; Van Der Borght, M.; Callens, A.; Van Campenhout, L. Suitability of microwave drying for mealworms (Tenebrio molitor) as alternative to freeze drying: Impact on nutritional quality and colour. Food Chem. 2018, 254, 129-136. [CrossRef]

26. Yamamoto, A.; Ono, K.; Machino, E.; Takasu, M.; Imaeda, N. Effect of particle size of brown rice on digestibility of energy and crude protein in growing-finishing pigs. Nihon Yot. Gakkaishi 2016, 53, 137-142. [CrossRef]

27. Watanabe, G.; Motoyama, M.; Nakajima, I.; Sasaki, K. Relationship between water-holding capacity and intramuscular fat content in Japanese commercial pork loin. Asian-Australas. J. Anim. Sci. 2018, 31, 914-918. [CrossRef] [PubMed]

28. Kim, T.W.; Kim, C.W.; Yang, M.R.; Kim, S.W.; Kim, I.S. Pork quality traits according to postmortem pH and temperature in Berkshire. Korean J. Food Sci. Anim. Resour. 2016, 36, 29-36. [CrossRef] [PubMed]

29. Yalçin, S.; Güler, H.C.; Yaşa, I.; İzzetoğlu, G.T.; Özkan, S. Effect of breeder age and slaughter weight on meat quality traits of broiler breast and leg meats. Eur. Poult. Sci. 2014, 78, 1-10. [CrossRef]

30. Debut, M.; Berri, C.; Baéza, E.; Sellier, N.; Arnould, C.; Guémené, D.; Jehl, N.; Boutten, B.; Jego, Y.; Beaumont, C.; et al. Variation of chicken technological meat quality in relation to genotype and preslaughter stress conditions. Poult. Sci. 2003, 82, 1829-1838. [CrossRef] [PubMed]

31. Karunanayaka, D.S.; Jayasena, D.D.; Jo, C. Prevalence of pale, soft, and exudative (PSE) condition in chicken meat used for commercial meat processing and its effect on roasted chicken breast. J. Anim. Sci. Technol. 2016, 58, 27. [CrossRef] [PubMed]

32. Bovera, F.; Loponte, R.; Marono, S.; Piccolo, G.; Parisi, G.; Iaconisi, V.; Gasco, L.; Nizza, A. Use of Tenebrio molitor larvae meal as protein source in broiler diet: Effect on growth performance, nutrient digestibility, and carcass and meat traits. J. Anim. Sci. 2016, 94, 639-647. [CrossRef] [PubMed]

33. Musa, H.H.; Chen, G.H.; Cheng, J.H.; Shuiep, E.S.; Bao, W.B. Breed and sex effect on meat quality of chicken. Int. J. Poult. Sci. 2006, 5, 566-568. [CrossRef]

34. Gallardo, M.A.; Pérez, D.D.; Leighton, F.M. Modification of fatty acid composition in broiler chickens fed canola oil. Biol. Res. 2012, 45, 149-161. [CrossRef]

35. Loponte, R.; Bovera, F.; Piccolo, G.; Gasco, L.; Secci, G.; Iaconisi, V.; Parisi, G. Fatty acid profile of lipids and caeca volatile fatty acid production of broilers fed a full fat meal from Tenebrio molitor larvae. Ital. J. Anim. Sci. 2019, 18, 168-173. [CrossRef]

36. Makkar, H.P.S.; Tran, G.; Heué, V.; Ankers, P. State-of-the-art on use of insects as animal feed. Anim. Feed Sci. Technol. 2014, 197, 1-33. [CrossRef]

37. Diener, S.; Zurbrügg, C.; Tockner, K. Bioaccumulation of heavy metals in the black soldier fly, Hermetia illucens and effects on its life cycle. J. Insects Food Feed 2015, 1, 261-270. [CrossRef]

38. Moniello, G.; Ariano, A.; Panettieri, V.; Tulli, F.; Olivotto, I.; Messina, M.; Randazzo, B.; Severino, L.; Piccolo, G.; Musco, N.; et al. Intestinal morphometry, enzymatic and microbial activity in laying hens fed different levels of a Hermetia illucens larvae meal and toxic elements content of the insect meal and diets. Animals 2019, 9, 86. [CrossRef]

39. Korish, M.A.; Attia, Y.A. Evaluation of heavy metal content in feed, litter, meat, meat products, liver, and table eggs of chickens. Animals 2020, 10, 727. [CrossRef] [PubMed]

40. Nimni, M.E.; Han, B.; Cordoba, F. Are we getting enough sulfur in our diet? Nutr. Metab. 2007, 4, 24. [CrossRef] 